\title{
The Effect of Water Saturation on the Ultrasonic Pulse Velocities of Different Stones
}

\author{
Ali Besharatinezhad ${ }^{1 *}$, Mohammad Ali Khodabandeh¹, Nikoletta Rozgonyi-Boissinot ${ }^{1}$, Ákos Török \\ ${ }^{1}$ Department of Engineering Geology and Geotechnics, Faculty of Civil Engineering, Budapest University of Technology and \\ Economics, Műegyetem rkp. 3., H-1111 Budapest, Hungary \\ * Corresponding author, e-mail: ali.besharati@emk.bme.hu
}

Received: 03 June 2021, Accepted: 22 January 2022, Published online: 18 February 2022

\begin{abstract}
Water saturation is considered one of the major factors influencing stones deterioration. The effect of moisture on the deterioration process of stone was investigated with the help of ultrasonic wave velocities. $\mathrm{P}$ and $\mathrm{S}$ waves velocities were calculated for twelve different lithotypes including limestone (porous limestone, laminated and less-laminated travertine, cemented limestone), sandstone and basalt. Water saturation tests were carried out based on the standard procedure of EN 13755. With the help of the Geotron device, $\mathrm{P}$ and $\mathrm{S}$ waves velocities in dry condition and during water saturation test were measured. Changes in physical parameters of stones (dynamic modulus of elasticity and Poisson's ratio) were calculated based on ultrasonic results. The results showed that changes in water contents did not correlate linearly with ultrasonic pulse velocity and $\mathrm{S}$ wave velocity was more sensitive to water content. The various limestone lithologies show distinct water saturation patterns. The influence of micro cracks and discontinuities on ultrasonic pulse velocity of saturated samples were analyzed and higher shear wave velocity was considered due to connectivity of pores and cracks and their ability for absorb water. There was a nonlinear relationship between Dynamic modulus of elasticity and porosity and high porous stones had a lower Modulus of elasticity than less porous stones. During water saturation, the Modulus of elasticity increased for all the stones.
\end{abstract}

Keywords

water saturation, porous stones, ultrasonic waves velocities, dynamic modulus of elasticity

\section{Introduction}

One of the main factors in stone deterioration is moisture transport in porous media. Water can enter the stone through its pores in a variety of ways. As a result, investigating the moisture transport in natural building stones is crucial for their preservation $[1,2]$.

Çelik and Kaçmaz [3] considered the effect of water saturation on the deterioration of tuff stones in the presence of clean water and salty water. They found out that water is one of the main factors responsible for the destruction of stone structures. It was assessed higher water absorption led to higher damage potential. However, the process of saturation was affected by salts and capillary water uptake of stones was higher in salty water conditions than in clean water. Water absorption of porous limestone and sandstone was studied by Cnudde et al. [1] and the results indicated that heterogeneity changes the capillarity of stones and as porosity increased the water uptake volume rose.
Uniaxial compressive strength and tesnile strength are among two main strength parameters that affected by water saturation changes [4-11]. It is necessary to consider the differences in dry and saturated strength parameters for design purposes and maintenance of stone structures. A 34\% decrease was measured at porous limestone [4]. For sandstones, shear strength and Brazilian tensile strength experinced a significant reduction (50.6-77.2\%) [6]. Similarly, by analyzing the previous published data, mechanical parameters of intact rocks in saturated condition were investigated by Vásárhelyi and Davarpanah [9] and the same results were observed.

Vásárhelyi and Gálos [10] studied different types of tuffs (andesite tuffs, basalt tuffs, and rhyolitic tuffs) to investigate the effect of water saturation on the strength parameters of samples. They concluded that UCS increased as density rose. Mechanical parameters of samples including 
dynamic Young's modulus, UCS and also UPV decreased after water saturation. Rabat et al. [11] studied the effect of moisture on strength and deformability of four porous calcarenite stones. In saturated condition, UCS and dynamic Young's modulus reduced by half of avearage values.

Ultrasonic wave velocity measurement is a non-destructive method that helps researchers and engineers investigate stone properties [12-15]. Karakul and Ulusay [12] found out that $\mathrm{P}$ wave velocity is affected by porosity and water content. Stones with higher porosity had lower $\mathrm{P}$ wave velocity and with increasing water content, $\mathrm{P}$ wave velocity rose. Siegesmund and Dürrast, [13] found that the deterioration process led to higher porosity and more water absorption. They concluded that only accessible pores are responsible for water absorption, not the total porosity of the stone. Çelik [14] investigated that the porosity of travertine increased after 25 freeze-thaw cycles and consequently, the water absorption rose. $\mathrm{P}$ wave velocity increased after water saturation and the freeze-thaw process by up to $5 \%$. Vasconcelos et al. [15] measured UPV of the granite and basalt in dry and wet conditions in different frequencies (54 and $150 \mathrm{kHz}$ ). They observed that differences between UPV output for these two frequencies were on average $2 \%$. The ultrasonic velocity of higher frequency $(150 \mathrm{kHz})$ was greater than that of lower frequency $(50 \mathrm{kHz})$. Moisture had a significant effect on UPV for granite and basalt and UPV increased after water saturation.

The effect of samples dimension on UPV for different types of stones (limestone, travertine, basalt, tuff, granite, dolomite, ignimbrite and andesite) were analyzed by Fener [16]. They considered 9 different core lithotypes at 6 different diameters. Generally, it was observed as diameter increased, P wave velocity decreased, but for 5 lithotypes including granite and travertine, a significant increase in $\mathrm{P}$ wave velocity was concluded. They have revealed that other physical parameters of stone types, such as porosity and density had a significant influence on $\mathrm{P}$ wave velocity changes, as well as sample dimension. The ultrasonic pulse velocities were low for less porous sample and there was a polynomial relationship between these physical parameters and $P$ wave velocity.

Ersoy et al. [17] studied the effect of dimension of specimens (height and diameter) and ultrasonic measurement technique (like direct, semi-direct or indirect) of ultrasonic pulse velocity. The influence of sample homogeneity on UPV was reduced by using homogeneous samples such as polypropylene, marble, and concrete. However, it was observed that changes in diameter or height did not have a significant influence in UPV. The change of $\mathrm{P}$ wave velocity of sample with length larger than $20 \mathrm{~cm}$ for different measurement techniques was less than $3 \%$. They found that the material homogeneity was more important than sample diameter, length, or measuring procedures in determining the $\mathrm{P}$ wave velocity of the materials. The effect of samples dimension on water absorption rate was studied by Çobanoğlu et al. [18]. It was concluded that the size of stones (limestone, sandstone and cement mortar) had a significant influence on saturation rate. For example, samples with a higher diameter $(54 \mathrm{~mm})$ had a lower water saturation rate than samples with a diameter between 21 to $30 \mathrm{~mm}$. However, in the present study, the main focus was on ultrasonic wave propagation during water saturation.

Trying to understand the effect of water content on strength parameter of stones, Zhuang et al. [19] considered granite in both dry and wet condition. It was revealed that after saturation, $\mathrm{P}$ and $\mathrm{S}$ waves velocity increased by up to 27 and $13 \%$ respectively. saturation decreased strength parameters of stone. UCS decreased at least by $3 \%$ and tensile strength of sample experienced 3 to $9 \%$ reduction. Dynamic elastic modulus and Poisson's ratio did not change significantly. Török and Vásárhelyi [20] investigated the effect of water saturation on the strength parameters of laminated and non-laminated travertines. They measured ultrasonic pulse velocity with a direct pulse transmission technique in wet and dry conditions. The porosity of the travertines ranged from 2.1 to $13.1 \mathrm{~V} \%$. After water saturation, ultrasonic pulse velocity increased for both laminated and non-laminated travertines. Non-laminated travertine had a higher density, ultrasonic pulse velocity, UCS, and porosity than laminated travertine. Pápay and Török [21] found out that the freeze-thaw cycle increase the mass and pores of the samples and also opening up the microcacks and consequently cause more water absorption and strength reduction. Cheng et al. [22] investigated the changes of $\mathrm{P}$ and $\mathrm{S}$ waves velocities for carbonate, sandstone and volcanic rocks at full-water and full-gas (nitrogen) saturation. Ultrasonic waves velocities ( $\mathrm{P}$ and $\mathrm{S}$ waves velocities) decreased as porosity increased and they found a linear positive relationship between $\mathrm{P}$ and $\mathrm{S}$ waves velocities. The results related to full water saturation were higher than that of full gas saturation.

In this study, on twelve different samples (limestone, sandstone, and basalt) with various physical properties water saturation tests were performed according to the standard procedure as described in [13]. Ultrasonic pulse velocities ( $\mathrm{P}$ and $\mathrm{S}$ waves velocities) were measured by Geotron device during the water absorption. 


\section{Materials and methods}

Twelve cylindrical specimens from 5 different stone types (basalt, sandstone, travertine, cemented limestone, bioclastic and oolitic limestones) were investigated. Lithology, geological age and some physical properties of samples (dried density and apparent porosity) was presented in Table 1 .

The diameter of stones was between 30 and $71 \mathrm{~mm}$ and the height of stones was between 36 and $110 \mathrm{~mm}$. Limestones had different porosities and geological ages. Macroscopic fabric images of the stones are shown in Fig. 1. The apparent porosity and the density of the stones were between 0.49 and $29.61 \mathrm{~V} \%$ and between 1.556 and $3.372 \mathrm{gr} / \mathrm{cm} 3$, respectively. Bioclastic and oolitic limestones had the highest porosity (29.61 and $22.24 \mathrm{~V} \%$ ), they were coarse-grained and had macropores between 1 and 5 $\mathrm{mm}$ and a maximum grain size of $5 \mathrm{~mm}$. The black basalt had the lowest porosity $(0.49 \mathrm{~V} \%)$ and the highest dried density (3.372 gr/cm3) between all the samples. There were two less-laminated and one laminated travetines with macropores ranged from 1 to $3 \mathrm{~mm}$, whereas micropores were found in cemented limestones, sandstones, and basalt. Travertines had a higher porosity and less dried density compared with cemented limestones, sandstones or basalt.

Table 1 Physical properties of the stones

\begin{tabular}{|c|c|c|c|}
\hline Lithology (abbreviation) & $\begin{array}{l}\text { Geological } \\
\text { age }\end{array}$ & $\begin{array}{c}\text { Dried } \\
\text { density } \\
\left(\mathrm{gr} / \mathrm{cm}^{3}\right)\end{array}$ & $\begin{array}{c}\text { Apparent } \\
\text { porosity } \\
(\mathrm{V} \%)\end{array}$ \\
\hline Black basalt (B1) & Pliocene & 3.3720 & 0.49 \\
\hline Red sandstone (S1) & Permian & 2.6170 & 2.87 \\
\hline $\begin{array}{l}\text { Brown limonitic sandstone } \\
\text { (S2) }\end{array}$ & Oligocene & 2.5714 & 3.60 \\
\hline $\begin{array}{l}\text { Creamy low porosity less- } \\
\text { laminated travertine (T1) }\end{array}$ & Pleistocene & 2.3954 & 5.83 \\
\hline $\begin{array}{l}\text { Beige low porosity less- } \\
\text { laminated travertine (T2) }\end{array}$ & Pleistocene & 2.5387 & 4.39 \\
\hline $\begin{array}{l}\text { Beige porous laminated } \\
\text { travertine (T3) }\end{array}$ & Pleistocene & 2.1368 & 9.76 \\
\hline $\begin{array}{l}\text { Creamy stylolitic cemented } \\
\text { limestone (L1) }\end{array}$ & Cretaceous & 2.5137 & 5.11 \\
\hline $\begin{array}{l}\text { Brownish mottled stylolitic } \\
\text { cemented limestone (L2) }\end{array}$ & Triassic & 2.6855 & 1.20 \\
\hline $\begin{array}{l}\text { Yellowish stylolitic } \\
\text { cemented limestone (L3) }\end{array}$ & Jurassic & 2.6654 & 1.35 \\
\hline $\begin{array}{l}\text { Red stylolitic nodular } \\
\text { limestone (L4) }\end{array}$ & Jurassic & 2.6878 & 1.12 \\
\hline $\begin{array}{l}\text { High porous bioclastic } \\
\text { limestone (PL1) }\end{array}$ & Miocene & 1.5566 & 29.61 \\
\hline $\begin{array}{l}\text { High porous oolitic } \\
\text { limestone (PL2) }\end{array}$ & Miocene & 1.7332 & 22.24 \\
\hline
\end{tabular}

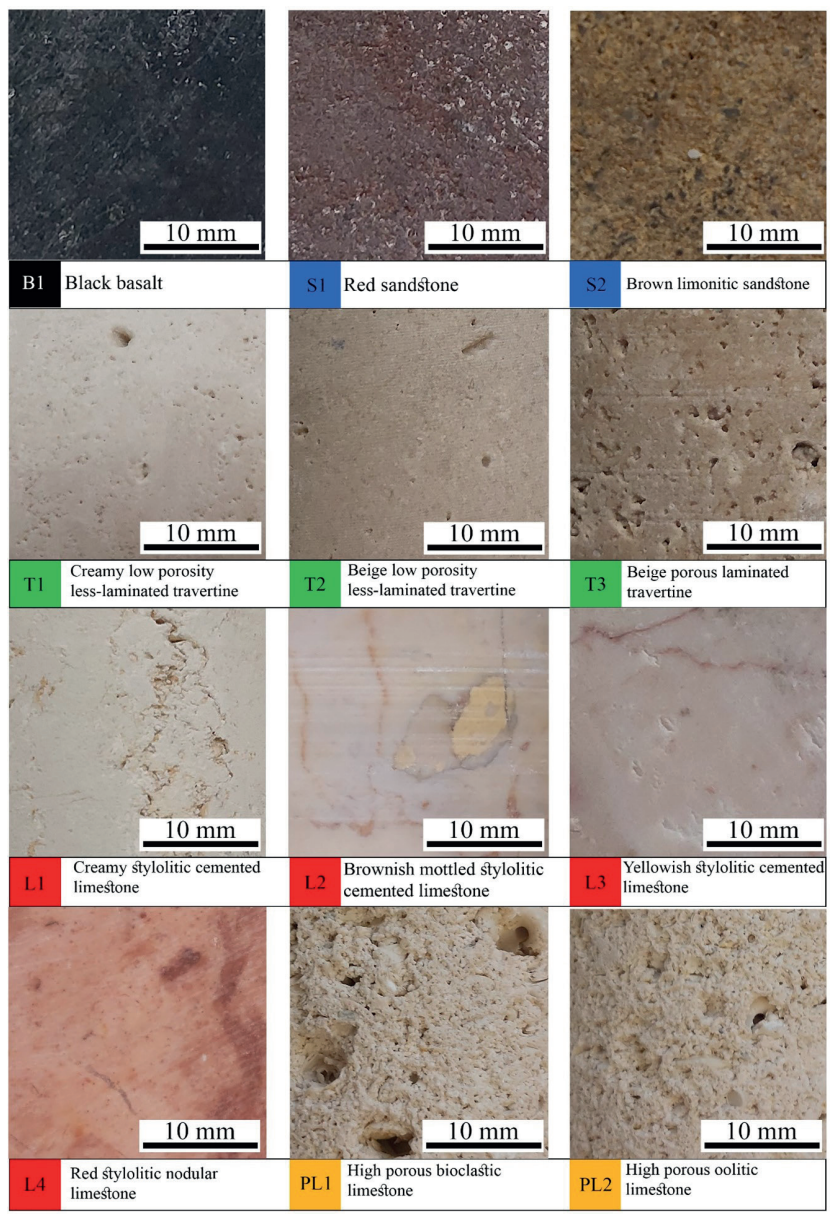

Fig. 1 Macroscopic fabric images of the tested stones

Because of the presence of cracks, the porosity of creamy stylolitic cemented limestone was higher than that of other cemented limestones.

Based on the standard procedure described in [13], water saturation under atmospherically pressure test for all the specimens was performed. At the first step, the stones were dried at $105^{\circ} \mathrm{C}$ for 48 hours. The dried stones were initially immersed in water up to half of their height. The samples were weighed, and ultrasonic pulse velocities were determined each minute from 1 to 10 and after 15 and 30 minutes. After 1 hour, water was added until it reached three-quarters of the height of the samples, and the weight and ultrasonic pulse velocity measurements were repeated. After 2 hours, water was added until the specimens were fully immersed in water to a depth of $25+5 \mathrm{~mm}$ and the weight and ultrasonic pulse velocities of the samples were measured. The process was repeated every $24 \pm 2$ hours.

The ultrasonic measurement was performed with Geotron device (frequency of $80 \mathrm{kHz}$ ). $\mathrm{P}$ and $\mathrm{S}$ waves velocities from Geotron were analysed based on Rozgonyi-Boissinot et al. [23]. In this study, dynamic modulus of elasticity $\left(E_{d y n}\right)$ 
and Poisson ratio were calculated as a function of $\mathrm{P}$ and S waves velocities and density (Eqs. (1) and (2)) [24, 25]:

$$
\begin{aligned}
& E_{d y n}=\frac{\rho v_{s}^{2}\left(3 v_{p}^{2}-4 v_{s}^{2}\right)}{v_{p}^{2}-v_{s}^{2}}, \\
& v_{d y n}=\frac{v_{p}^{2}-2 v_{s}^{2}}{2\left(v_{p}^{2}-v_{s}^{2}\right)} .
\end{aligned}
$$

Where $v_{P}$ is $\mathrm{P}$ wave velocity and $v_{S}$ is $\mathrm{S}$ wave velocity and $\rho$ is density of stones. The direction of lamination for laminated and less-laminated travertines was perpendicular to the wave propagation direction.

\section{Results}

The effect of dried density $\left(\rho_{d}\right)$, saturated density $\left(\rho_{s}\right)$ and porosity $(n)$ on the $\mathrm{P}$ and $\mathrm{S}$ waves velocities were plotted (Fig. 2). A linear trend is found between ultrasonic waves velocities and dried and saturated densities. The results show that stones with a higher dried and saturated density had higher $\mathrm{P}$ and $\mathrm{S}$ waves velocities. The dried density of basalt was at least $37 \%$ higher than the average dried density of all other studied stones, and it had the highest $\mathrm{P}$ and $\mathrm{S}$ waves velocities. For bioclastic and oolitic porous limestones, which had the lowest dried densities (1.556 and $1.733 \mathrm{gr} / \mathrm{cm}^{3}$ ), the results of $\mathrm{P}$ and $\mathrm{S}$ waves velocities were lower than the rest of the stones. The average porosity of bioclastic and oolitic porous limestones was higher than the average of all the samples. That explained the great differences in ultrasonic waves velocities between these stones and others. For denser stones, the differences between $P$ and $\mathrm{S}$ waves velocities were higher in comparison with porous ones in both dry and saturated conditions. Because the increasing rate of $\mathrm{P}$ wave velocity was higher than $\mathrm{S}$ wave velocity in denser stones. Ultrasonic waves velocities against porosity were plotted in Fig. 2(c). Unlike density that had a positive trend with increasing ultrasonic waves velocities, porosity showed a negative non-linear trend with ultrasonic velocities. For stones with higher porosity, the $\mathrm{P}$ and $\mathrm{S}$ waves velocities were less than low porous stones. For stones with higher porosity, the curve tended to be more flatten which proved that the differences in ultrasonic waves velocities was less sensitive to porosity for high porous stones (like bioclastic and oolitic limestone).

The results of water saturation tests for samples are presented in Fig. 3. The curves could be divided into three zones. In the first zone, water absorption and water content increased rapidly and linearly with the square root of time until $30 \mathrm{~s}^{0.5}$. The second zone started from $30 \mathrm{~s}^{0.5}$ and

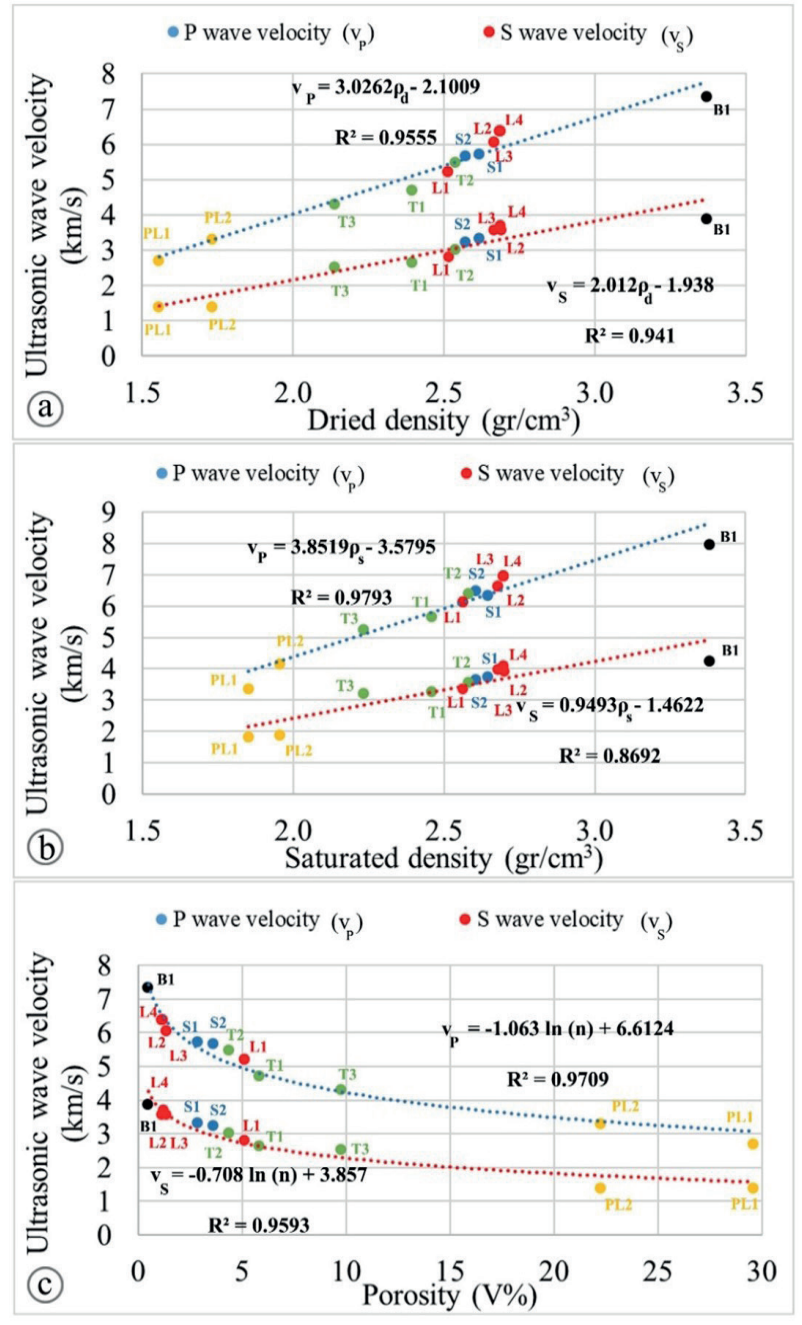

Fig. 2 a) $P$ and $S$ waves velocities vs. dried density, b) $P$ and $S$ waves velocities vs. saturated density c) $\mathrm{P}$ and $\mathrm{S}$ waves velocities vs. porosity ( $n$ )

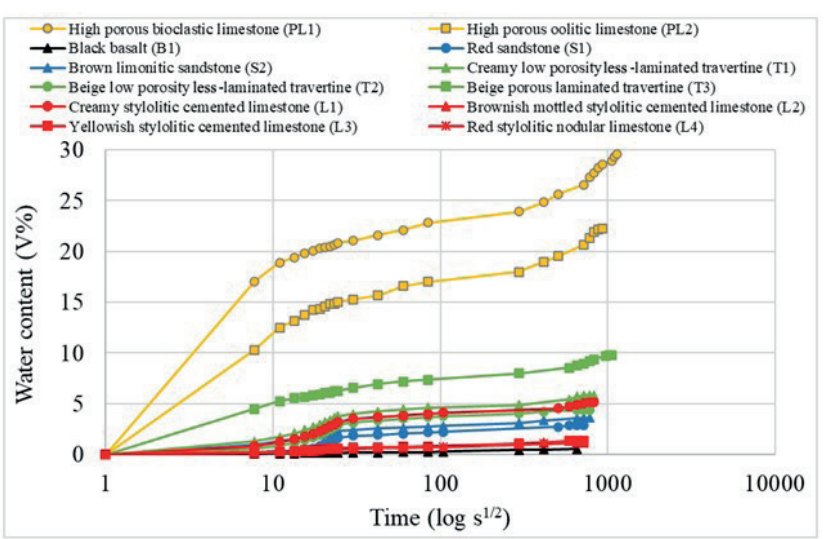

Fig. 3 The results of water saturation test for all the samples a) water content (V\%) vs. time, b) enlarged graph for water content (V\%) vs. time

continued until $600 \mathrm{~s}^{0.5}$ which had a gradual trend, and the slope of the curve was smoother in comparison with the first phase. The third zone started from $600 \mathrm{~s}^{0.5}$, and the stones experienced very slow water absorption trends 
until they became completely saturated. The results show that the slope of the curves was different for all samples. As density reduced, the slope of the curve in the first phase increased and the amount of water absorption decreased. Basalt and high porous bioclastic limestone had the lowest and the highest slope of the curves in the first phase, respectively. High porous bioclastic and oolitic limestones had the highest absorbed water in the first phase in comparison with the rest of the specimens. Their water uptake level was significantly different in comparison with other samples. The reason behind this, is the high porosity of these two samples. Their average porosity $(25.93 \%)$ were almost 7 times higher than average porosity (3.57\%) of other samples. With a more detailed look at the Fig. 3, it is obvious that slope of the curve at the third phase for oolitic and bioclastic limestone are significantly higher in comparison with other samples, which indicate that water absorption capability at third phase is still affected by porosity.

Travertines are the second most porous stones in the tests, and their water absorption trend in the first phase indicated their high porosity. Their second and third phases followed each other with smoother slopes, and the differences between two phases was less significant compared to high porous bioclastic and oolitic limestones.

However, laminated travertine had higher porosity than less-laminated travertines. Laminated travertine became saturated later than two less-laminated ones and its first phase was steeper in comparison with the others. It seems that water absorption process and ultrasonic waves velocities was affected by the layered structure of laminated travertine.

It can be concluded that the stone structure is one of the most important factors influencing the physical properties of stones. The third group were sandstones which had less porosity rather than two first mentioned groups of stones. Their first phase experienced slower trend compared to porous ones. However, the second and third phases of these sandstone samples were also smoother than porous samples, but the differences were not as significant as the first phase (Fig. 4). The group of cemented limestones had higher density and lower porosity in comparison with prior stones except creamy stylolitic cemented limestone (Fig. 4). Finally, in comparison with all the samples the densest stone was basalt with lowest slope in its first phase and it was saturated earlier than other samples (Fig. 4). The water absorption curves of the three cemented limestones (brownish mottled stylolitic cemented limestone, yellowish stylolitic cemented limestone, and red stylolitic

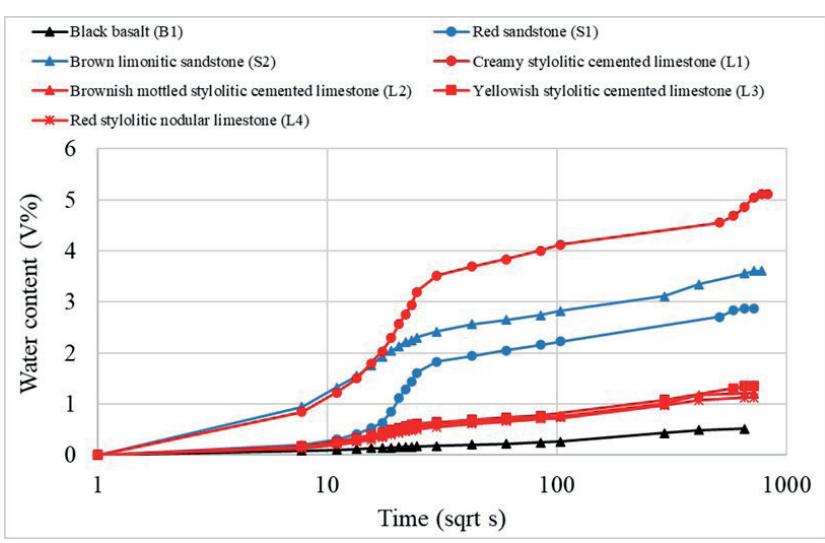

Fig. 4 The results of water saturation test for basalt, sandstones, and cemented limestones

nodular limestone) have the same pattern (Fig. 4). However, creamy stylolitic cemented limestone considered as an exception due to the existence of cracks that increased the water absorption. After $600 \mathrm{~s}^{0.5}$, only the porous samples experienced some changes in their water content. The stones absorbed the most water volume in their first phase and stones with lower porosity became completely saturated earlier than porous ones. The slope of the curves at the first phase for densest stone (basalt) to the most porous stone (high porous bioclastic limestone) were 0.012 and 2.53 , respectively, which indicate the significant influence of density and porosity as two main physical parameters of stones on water uptake level.

The degree of saturation against time for high porous bioclastic and oolitic limestones, travertines, cemented limestones, sandstones, and basalt were presented in Figs. 5(a), 5(b), 5(c) and 5(d), respectively. The results show two different trends for porous and dense limestones.

The porous limestones experienced almost $70 \%$ of their saturation degree at initial phase (Figs. 5(a) and 5(b)), while three denser samples saturated only around $50 \%$ in this period of time (Fig. 5(c)). A slower uptake at porous stones follows the rapid initial water uptake phase. Denser limestones (like brownish mottled stylolitic cemented limestone, yellowish stylolitic cemented limestone, and red stylolitic nodular limestone) were the first ones that reached completely saturation.

High porous bioclastic and oolitic limestones reached their full saturation later than others. Laminated travertine had a different form of the curve in comparison with less-laminated ones (Fig. 5(b)). Due to the existence of cracks, the saturation degree increased rapidly at the first phase. For less-laminated travertines water saturation process followed a gradual increasing trend in the initial stage. 


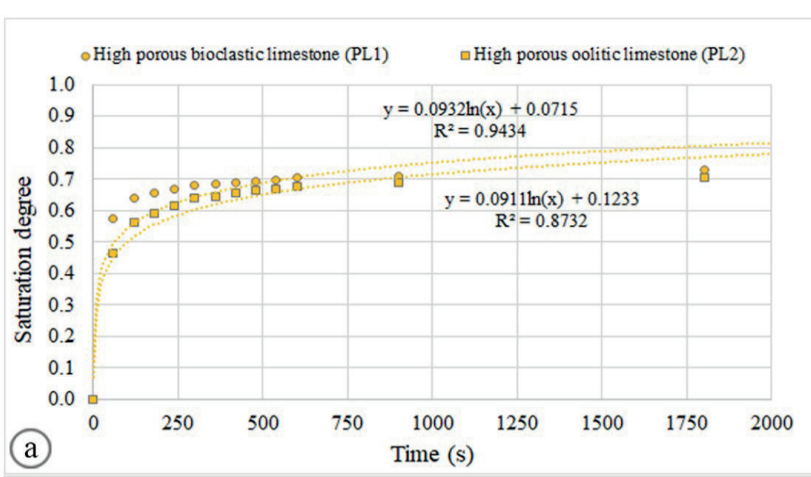

$\triangle$ Creamy low porosity less-laminated travertine $(\mathrm{T} 1) \quad \bullet$ Beige low porosity less-laminated travertine $(\mathrm{T} 2)$
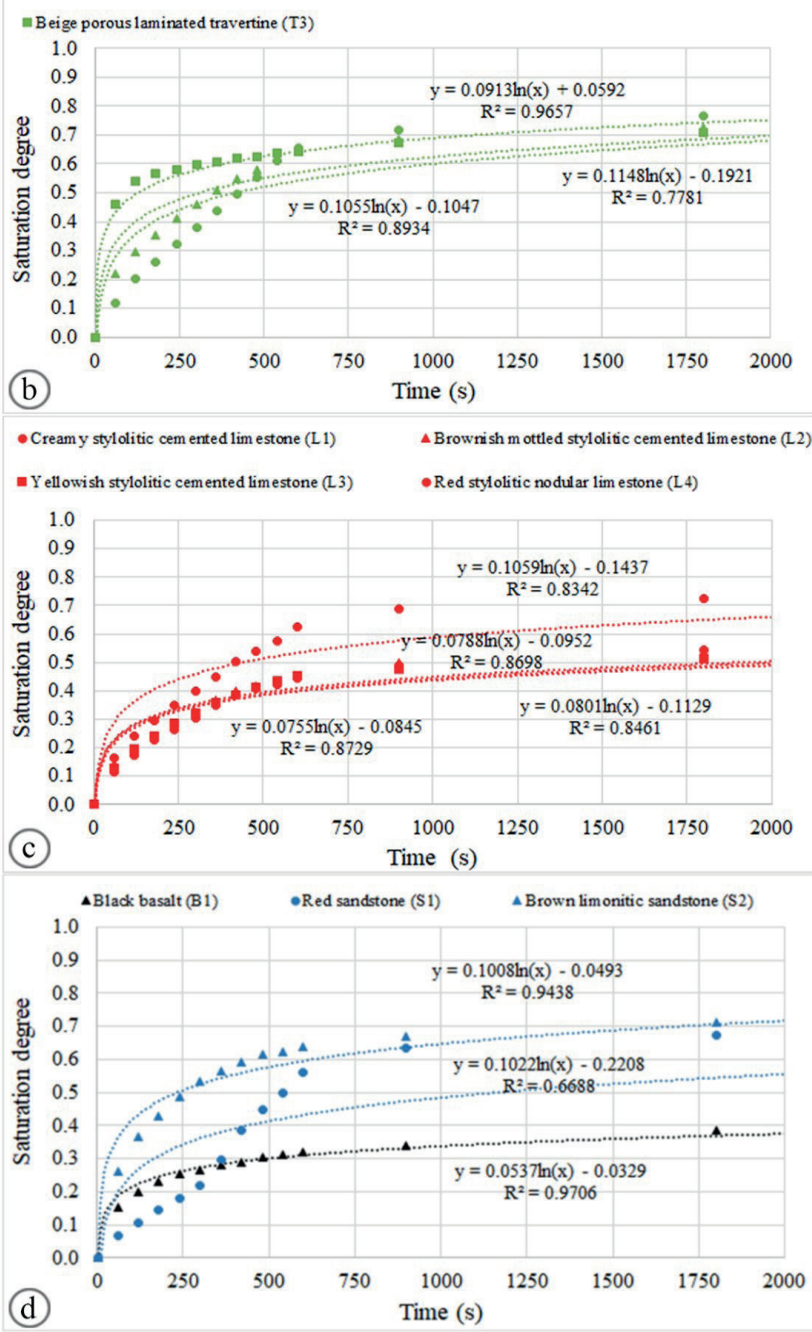

Fig. 5 The degree of saturation (\%) vs. time a) high porous bioclastic and oolitic limestones, b) travertines, c) cemented limestones, d) basalt and sandstones

Two sandstones had different water uptake at the initial saturation phase, but the trend became similar after the rapid uptake after about 15 minutes (Fig. 6(d)). The different trend of water absorption at the initial phase was due to the different pore structures in these two sandstones. They obtained approximately $65 \%$ of their saturation at the end

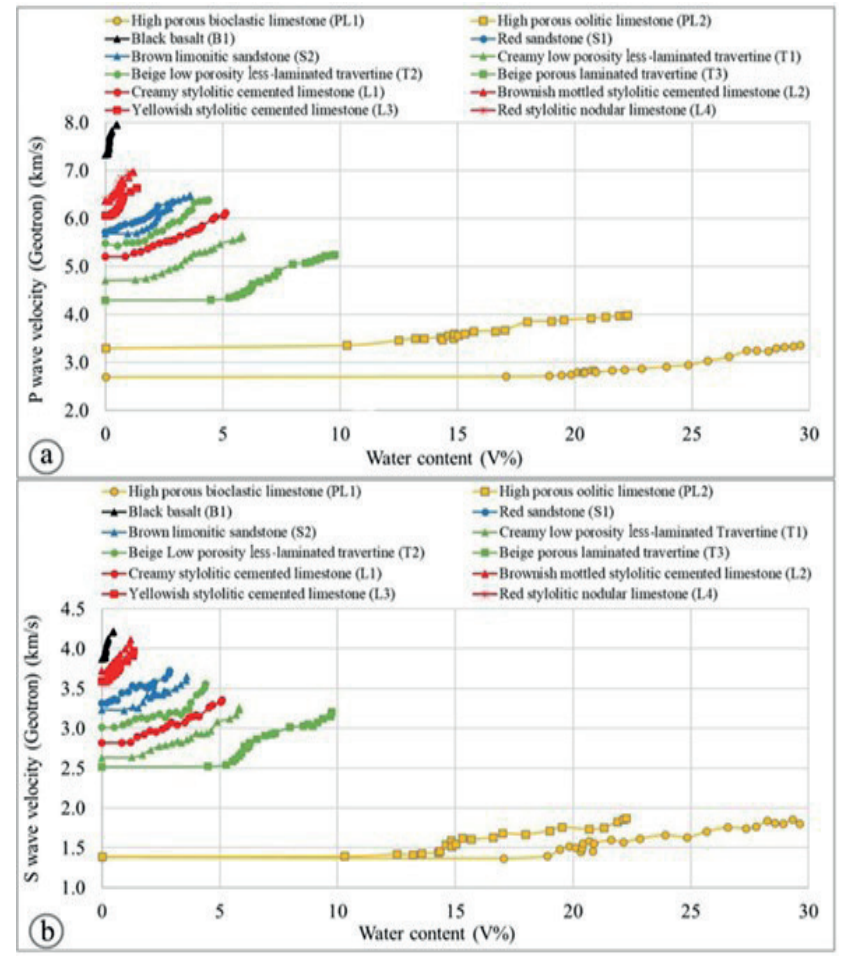

Fig. 6 The results of water saturation test a) P wave velocity (Geotron) vs. water content (V\%), b) S wave velocity (Geotron) vs. water content (V\%)

of the first phase. The lithotypes with higher density had a different saturated trend. At the initial stage, the volcanic basalt reached $35 \%$ of its full saturation, and it took the shortest time to reach full saturation. (Fig. 5(d)). The regression curves are logarithmic and they experienced an steep rising at first phase and after that it was followed by a slower trend.

The $\mathrm{P}$ and $\mathrm{S}$ waves velocities versus water content (V\%) for Geotron measurement were presented in Fig. 6. $\mathrm{P}$ wave velocity was higher for stones with higher density and lower porosity. The changes of $\mathrm{P}$ wave velocity were more significant for stones with higher porosity and lower density and they were $8.51 \%$ and $24.94 \%$ from the densest stone to the most porous one, respectively.

A more detailed look at Fig. 6(a) reveals that $\mathrm{P}$ wave velocities rose moderately at the first stage of water absorption. However, an abrupt increase for $\mathrm{P}$ wave velocities were observed after the samples reached their saturation state. The $\mathrm{S}$ wave velocities versus water content (V\%) were presented in Fig. 6(b). The S wave velocity followed the same trend as the $\mathrm{P}$ wave velocity, although its trend was more fluctuated. The $\mathrm{S}$ wave velocity rose as the water content (V\%) increased. Creamy stylolitic cemented limestone had lower $\mathrm{P}$ and $\mathrm{S}$ waves velocities rather than other cemented limestones due to pre-existing cracks. Dynamic 
modulus of elasticity was considered to investigate the effect of water saturation on physical parameters of stones. In Fig. 7 the changes of dynamic modulus of elasticity against porosity is presented. Negative exponential relationship between porosity and modulus of elasticity indicated that stones with higher porosity had a lower modulus of elasticity as a function of $\mathrm{P}$ and $\mathrm{S}$ waves velocities.

The values of modulus of elasticity and Poisson ratio are presented in Table 2. In both dry and water saturation conditions, basalt had the highest amount of $E_{d y n}$ with 132.2 GPa, whereas high porous bioclastic limestone had the lowest amount of $E_{d y n}$ around $7.9 \mathrm{GPa}$.

Yellowish stylolitic cemented limestone and high porous oolitic limestone had the lowest and highest dynamic Poisson ratio equal to 0.23 and 0.39 , respectively. After reaching fully water saturation, the modulus of elasticity rose in all samples. The changes of dynamic modulus of elasticity from the densest stone to the most porous

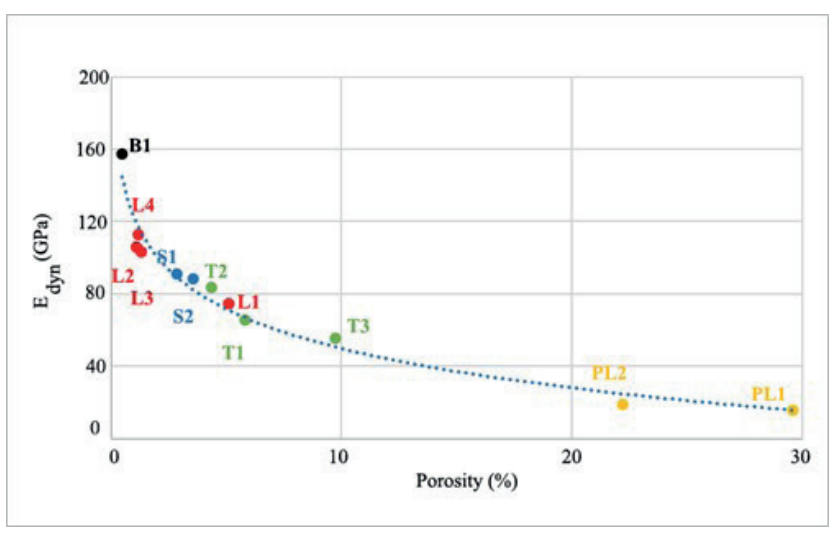

Fig. 7 Dynamic modulus of elasticity vs. porosity

Table 2 The changes of modulus of elasticity and Poisson ratio in dry and saturated condition

\begin{tabular}{|c|c|c|c|c|}
\hline \multirow{2}{*}{$\begin{array}{l}\text { Sample } \\
\text { code }\end{array}$} & \multicolumn{2}{|c|}{ Dry } & \multicolumn{2}{|c|}{ Saturated } \\
\hline & $v_{d y n}$ & $E_{d y n}(\mathrm{GPa})$ & $v_{d y n}$ & $E_{d y n}(\mathrm{GPa})$ \\
\hline B1 & 0.31 & 132.2 & 0.30 & 157.1 \\
\hline $\mathrm{S} 1$ & 0.25 & 71.7 & 0.24 & 90.6 \\
\hline $\mathrm{S} 2$ & 0.26 & 67.5 & 0.27 & 88.2 \\
\hline $\mathrm{T} 1$ & 0.27 & 42.2 & 0.26 & 65.3 \\
\hline $\mathrm{T} 2$ & 0.28 & 59.1 & 0.27 & 83.2 \\
\hline T3 & 0.24 & 33.5 & 0.22 & 55.0 \\
\hline L1 & 0.29 & 51.6 & 0.29 & 74.1 \\
\hline L2 & 0.24 & 92.1 & 0.23 & 112.3 \\
\hline L3 & 0.23 & 84.4 & 0.22 & 103.0 \\
\hline L4 & 0.27 & 87.5 & 0.27 & 105.8 \\
\hline PL1 & 0.32 & 7.9 & 0.30 & 15.6 \\
\hline PL2 & 0.39 & 9.4 & 0.37 & 18.8 \\
\hline
\end{tabular}

one were $18.82 \%$ and $101.4 \%$, respectively. In contrast to dynamic modulus of elasticity, the changes of Poisson's ratio were almost constant for all the samples.

\section{Discussion}

Porosity and density have a major effect on the water saturation process for stones. The results of the water saturation test demonstrated that stones with higher porosity experienced higher water absorption level and it take more time to become fully saturated in compare with low porosity stones. Cnudde et al. [1] also found out the positive relationship between porosity and water uptake for limestone and sandstone. Çelik and Kaçmaz [3] concluded that tuff stones with larger pore size absorbed more water content. A higher water uptake resulted greater damages. In the present study, water saturation process consists of three phases.

The form of the curves in the first phase for porous lithotypes (high porous bioclastic limestone, oolitic limestones and beige porous laminated travertine) were different from the other stones. In agreement with Cnudde et al. [1], stones with higher porosity and lower density achieved maximum of their degree of saturation in the first stage of the test and water uptake decreased significantly in the second phase. The third phase was slower than previous phases and continued until fully saturated condition. Denser stones reached their complete saturation level earlier than porous ones. Different trends for high porous bioclastic and oolitic limestones were observed in comparison with other stones. It signifies that the porosity controls the water absorption trend.

Based on the type of stones, different increasing $P$ wave velocity trends were observed in saturated condition. Török and Vásárhelyi [20] concluded that non-laminated travertine had higher density, ultrasonic pulse velocity, UCS and lower porosity compared to laminated ones. In the present study, the same results for ultrasonic wave velocity were observed for laminated and less-laminated travertines and other types of stones. Laminated travertine was more porous than less-laminated ones and consequently the slope of the curve in the first phase was steeper for laminated travertine. The increasing rate of $\mathrm{P}$ wave velocity was higher in laminated travertine compared with less-laminated samples.

For laminated stones, the wave propagation was perpendicular to the stone planes. The effect of the orientation of stone planes on ultrasonic wave velocity were emphasized by other researchers [15, 26]. Vasconcelos et al. [15] also obtained that for laminated stones, the wave propagation 
direction was perpendicular with the stone planes. They concluded that the perpendicular direction of the planes can reduce the effect of anisotropy of the stones on ultrasonic wave velocity in saturated conditions with neglecting the presence of discontinuities and pre-existing cracks.

In term of $\mathrm{S}$ wave velocity, the same increasing trends for different types of stones were observed. The results of the present study were in agreement with Li et al. [27]. They observed an increasing trend for $\mathrm{S}$ wave velocity of porous sandstone after water saturation. In the present study, the negative relationship between porosity and modulus of elasticity was in agreement with Brotons et al. [28]. They observed an inverse proportional relationship between porosity and modulus of elasticity which means that high porous rocks had a lower elastic modulus than denser stones. They also concluded that pores structure and fissures had a great effect on modulus of elasticity and ultrasonic waves velocities. A positive relationship between $\mathrm{P}$ wave velocity and modulus of elasticity in dry condition was in agreement with the results of the present study. Zhuang et al. [19] found out that the existence of well-connected micro cracks and porosity influenced ultrasonic pulse velocity. Modulus of elasticity and Poisson's ratio had a negligible change after saturation. These results were in agreement with the results of the present study. However, in the present study Poisson's ratio did not also changed significantly, but changes in dynamic modulus of elasticity was strongly related to the porosity of samples.

\section{References}

[1] Cnudde, V., Dierick, M., Vlassenbroeck, J., Masschaele, B., Lehmann, E., Jacobs, P., Van Hoorebeke, L. "High-speed neutron radiography for monitoring the water absorption by capillarity in porous materials", Nuclear Instruments and Methods in Physics Research Section B: Beam Interactions with Materials and Atoms, 266(1), pp. 155-163, 2008.

https://doi.org/10.1016/j.nimb.2007.10.030

[2] Kósa, Z., Török, Á. "Characterization of Historic Binders and Stones of a Ruined Medieval Church (Hungary)", Periodica Polytechnica Civil Engineering, 64(2), pp. 597-604, 2020. https://doi.org/10.3311/PPci.15599

[3] Çelik, M. Y., Kaçmaz, A. U. "The investigation of static and dynamic capillary by water absorption in porous building stones under normal and salty water conditions", Environmental Earth Sciences, 75(4), Article number: 307, 2016. https://doi.org/10.1007/s12665-015-5132-x

[4] Vásárhelyi, B. "Statistical analysis of the influence of water content on the strength of the Miocene limestone", Rock Mechanics and Rock Engineering, 38(1), pp. 69-76, 2005.

https://doi.org/10.1007/s00603-004-0034-3

\section{Conclusions}

Water saturation curves can be divided into three sections showing different slopes. As expected, the water content increased rapidly with time at porous lithotypes. However, the water absorption reduced after that, although it continued for more than two weeks for highly porous limestone. The water saturation has a different influence on $\mathrm{P}$ and $\mathrm{S}$ velocities. According to our measurements, S wave velocity changed more than $\mathrm{P}$ wave velocity after water saturation. Laminated travertine with higher porosity showed a rapid initial water absorption, but it required a longer time than the less-laminated travertine to reach full saturation. Comparison of different water absorption curves allows to compare the pore structure of various lithotypes, and it provides hints on the long-term durability. Microcracks and discontinuities within the fabric can influence ultrasonic pulse velocity and, consequently, mechanical parameters of stones. The connectivity and accessibility of these pores can be estimated using ultrasonic pulse waves of saturated samples. Namely, the higher pulse velocities of saturated vs. dry specimens suggest that the micro-crack system is connected and absorbs water.

\section{Acknowledgements}

The financial support of project no. BME-NVA-02, implemented with the support provided by the Ministry of Innovation and Technology of Hungary from the National Research, Development and Innovation Fund, financed under the TKP2021 funding scheme is acknowledged.

[5] Vásárhelyi, B., Ván, P. "Influence of water content on the strength of rock", Engineering Geology, 84(1-2), pp. 70-74, 2006.

https://doi.org/10.1016/j.enggeo.2005.11.011

[6] Zare Naghadehi, M., KhaloKakaie, R., Torabi, S. R. "The influence of moisture on sandstone properties in Iran", Proceedings of the Institution of Civil Engineers-Geotechnical Engineering, 163(2), pp. 91-99, 2010.

https://doi.org/10.1680/geng.2010.163.2.91

[7] Roy, D. G., Singh, T. N., Kodikara, J., Das, R. "Effect of water saturation on the fracture and mechanical properties of sedimentary rocks", Rock Mechanics and Rock Engineering, 50(10), pp. 2585-2600, 2017

https://doi.org/10.1007/s00603-017-1253-8

[8] Wong, L. N. Y., Maruvanchery, V., Liu, G. "Water effects on rock strength and stiffness degradation", Acta Geotechnica, 11(4), pp. 713-737, 2016.

https://doi.org/10.1007/s11440-015-0407-7

[9] Vásárhelyi, B., Davarpanah, M. "Influence of water content on the mechanical parameters of the intact rock and rock mass", Periodica Polytechnica Civil Engineering, 62(4), pp. 1060-1066, 2018. https://doi.org/10.3311/PPci.12173 
[10] Vásárhelyi, B., Gálos, M. "How does the water saturation influence the mechanical properties of the volcanic tuffs?", Periodica Polytechnica Civil Engineering, 48(1-2), pp. 65-72, 2004. [online] Available at: https://pp.bme.hu/ci/article/view/583

[11] Rabat, Á., Cano, M., Tomás, R. "Effect of water saturation on strength and deformability of building calcarenite stones: Correlations with their physical properties", Construction and Building Materials, 232, Article number: 117259, 2020. https://doi.org/10.1016/j.conbuildmat.2019.117259

[12] Karakul, H., Ulusay, R. "Empirical correlations for predicting strength properties of rocks from P-wave velocity under different degrees of saturation", Rock Mechanics and Rock Engineering, 46(5), pp. 981-999, 2013. https://doi.org/10.1007/s00603-012-0353-8

[13] Siegesmund, S., Dürrast, H. "Physical and mechanical properties of rocks", In: Siegesmund, S., Snethlage, R. (eds.) Stone in Architecture, Springer, Berlin, Heidelberg, Germany, pp. 97-225, 2011.

https://doi.org/10.1007/978-3-642-14475-2_3

[14] Çelik, M. Y. "Water absorption and P-wave velocity changes during freeze-thaw weathering process of crosscut travertine rocks", Environmental Earth Sciences, 76(12), Article number: 409, 2017.

https://oi.org/10.1007/s12665-017-6632-7

[15] Vasconcelos, G., Lourenço, P. B., Alves, C. A. S., Pamplona, J. "Ultrasonic evaluation of the physical and mechanical properties of granites", Ultrasonics, 48(5), pp. 453-466, 2008.

https://doi.org/10.1016/j.ultras.2008.03.008

[16] Fener, M. "The effect of rock sample dimension on the P-wave velocity", Journal of Nondestructive Evaluation, 30(2), pp. 99-105, 2011.

https://dx.doi.org/10.1007/s10921-011-0095-7

[17] Ersoy, H., Karahan, M., Babacan, A. E., Sünnetci, M. O. "A new approach to the effect of sample dimensions and measurement techniques on ultrasonic wave velocity", Engineering Geology, 251, pp. 63-70, 2019.

https://doi.org/10.1016/j.enggeo.2019.02.011

[18] Çobanoğlu, İ., Çelik, S. B., Dinçer, İ., Alkaya, D. "Core size and time effects on water absorption values of rock and cement mortar samples", Bulletin of Engineering Geology and the Environment, 68(4), Article number: 483, 2009.

https://doi.org/10.1007/s10064-009-0215-0

[19] Zhuang, L., Kim, K. Y., Diaz, M., Yeom, S. "Evaluation of water saturation effect on mechanical properties and hydraulic fracturing behavior of granite", International Journal of Rock Mechanics and Mining Sciences, 130, Article number: 104321, 2020. https://doi.org/10.1016/j.ijrmms.2020.104321
[20] Török, Á., Vásárhelyi, B. "The influence of fabric and water content on selected rock mechanical parameters of travertine, examples from Hungary", Engineering Geology, 115(3-4), pp. 237-245, 2010.

https://doi.org/10.1016/j.enggeo.2010.01.005

[21] Pápay, Z., Török, Á. "Effect of thermal and freeze-thaw stress on the mechanical properties of porous limestone", Periodica Polytechnica Civil Engineering, 62(2), pp. 423-428, 2018. https://doi.org/10.3311/PPci.11100

[22] Cheng, W., Ba, J., Fu, L.-Y., Lebedev, M. "Wave-velocity dispersion and rock microstructure", Journal of Petroleum Science and Engineering, 183, Article number: 106466, 2019. https://doi.org/10.1016/j.petrol.2019.106466

[23] Rozgonyi-Boissinot, N., Khodabandeh, M. A., Besharatinezhad, A., Török, Á. "Salt weathering and ultrasonic pulse velocity: condition assessment of salt damaged porous limestone", Mechanics and Rock Engineering, from Theory to Practice, IOP Conf. Series: Earth and Environmental Science, 833, Article number: 012070, 2021.

https://doi.org/10.1088/1755-1315/833/1/012070

[24] Davarpanah, S. M., Ván, P., Vásárhelyi, B. "Investigation of the relationship between dynamic and static deformation moduli of rocks", Geomechanics and Geophysics for Geo-Energy and GeoResources, 6(1), Article number: 29, 2020. https://doi.org/10.1007/s40948-020-00155-z

[25] Martinez-Martinez, J., Benavente, D., García-del-Cura, M. A. "Comparison of the static and dynamic elastic modulus in carbonate rocks", Bulletin of Engineering Geology and the Environment, 71(2), pp. 263-268, 2012. https://doi.org/10.1007/s10064-011-0399-y

[26] Barroso, C. E., Oliveira, D. V., Ramos, L. F. "Physical and mechanical characterization of vernacular dry stone heritage materials: Schist and granite from Northwest Portugal", Construction and Building Materials, 259, Article number: 119705, 2020. https://doi.org/10.1016/j.conbuildmat.2020.119705

[27] Li, D., Wei, J., Di, B., Ding, P., Huang, S., Shuai, D. "Experimental study and theoretical interpretation of saturation effect on ultrasonic velocity in tight sandstones under different pressure conditions", Geophysical Journal International, 212(3), pp. 2226-2237, 2018. https://doi.org/10.1093/gji/ggx536

[28] Brotons, V., Tomás, R., Ivorra, S., Grediaga, A., MartínezMartínez, J., Benavente, D., Gómez-Heras, M. "Improved correlation between the static and dynamic elastic modulus of different types of rocks", Materials and structures, 49(8), pp. 3021-3037, 2016.

https://doi.org/10.1617/s11527-015-0702-7 